\title{
BROOKHBVEN
}

NATIONAL LABORATORY

\section{LOCAL IMPACTS OF MERCURY EMISSIONS FROM THE MONTICELLO COAL FIRED POWER PLANT}

T. M. Sullivan ${ }^{1}$, J. Adams ${ }^{1}$, L. Milian ${ }^{1}$, S. Subramanian ${ }^{2}$, L. Feagin ${ }^{2}$, J. Williams ${ }^{2}$, and A. Boyd ${ }^{2}$

${ }^{1}$ Brookhaven National Laboratory, Upton, NY 11973-5000

${ }^{2}$ Miles College, Fairfield, AL

Progress Report to

the Department of Energy

National Energy Technology Laboratory, Mercury Deposition Near Coal-Fired Power Plants

October 2006

\author{
Environmental Sciences Department \\ Environmental Research \& Technology Division \\ Brookhaven National Laboratory \\ P.O. Box 5000 \\ Upton, NY 11973-5000 \\ www.bnl.gov
}

Notice: This manuscript has been authored by employees of Brookhaven Science Associates, LLC under Contract No. DE-AC0298CH10886 with the U.S. Department of Energy. The publisher by accepting the manuscript for publication acknowledges that the United States Government retains a non-exclusive, paid-up, irrevocable, world-wide license to publish or reproduce the published form of this manuscript, or allow others to do so, for United States Government purposes. 


\section{DISCLAIMER}

This report was prepared as an account of work sponsored by an agency of the United States Government. Neither the United States Government nor any agency thereof, nor any of their employees, nor any of their contractors, subcontractors, or their employees, makes any warranty, express or implied, or assumes any legal liability or responsibility for the accuracy, completeness, or any third party's use or the results of such use of any information, apparatus, product, or process disclosed, or represents that its use would not infringe privately owned rights. Reference herein to any specific commercial product, process, or service by trade name, trademark, manufacturer, or otherwise, does not necessarily constitute or imply its endorsement, recommendation, or favoring by the United States Government or any agency thereof or its contractors or subcontractors. The views and opinions of authors expressed herein do not necessarily state or reflect those of the United States Government or any agency thereof. 


\begin{abstract}
The Clean Air Interstate Rule (CAIR) and the Clean Air Mercury Rule (CAMR) as currently proposed by the U.S. Environmental Protection Agency (EPA) when fully implemented will lead to reduction in mercury emissions from coal-fired power plants by 70 percent to fifteen tons per year by 2018. The EPA estimates that mercury deposition would be reduced 8 percent on average in the Eastern United States.
\end{abstract}

The CAMR permits cap-and-trade approach that requires the nationwide emissions to meet the prescribed level, but do not require controls on each individual power plant. This has led to concerns that there may be hot-spots of mercury contamination near power plants. Partially because of this concern, many states including Pennsylvania have implemented, or are considering, state regulations that are stricter on mercury emissions than those in the CAMR.

This study examined the possibility that coal-fired power plants act as local sources leading to mercury "hot spots", using two types of evidence.. First, the world-wide literature was searched for reports of deposition around mercury sources, including coal-fired power plants. Second, soil samples from around two mid-sized U.S. coal-fired power plants were collected and analyzed for evidence of "hot spots" and for correlation with model predictions of deposition.

The following summarizes our findings from published reports on the impacts of local deposition. In terms of excesses over background the following increments have been observed within a few $\mathrm{km}$ of the plant:

- local soil concentration $\mathrm{Hg}$ increments of 30\%-60\%,

- sediment increments of $18-30 \%$, and

- wet deposition increments of 11-12\%.

- fish $\mathrm{Hg}$ increments of about 5-6\%, based on an empirical finding that fish concentrations are proportional to the square root of deposition.

Important uncertainties include possible reductions of $\mathrm{RGM}$ to $\mathrm{Hg}(0)$ in power plant plumes and the role of water chemistry in the relationship between $\mathrm{Hg}$ deposition and fish content.

Soil and vegetation sampling programs were performed around the Monticello coal fired power plant. The objectives were to determine if local mercury hot spots exist, to determine if they could be attributed to deposition of coal-fired power plant emissions, and to determine if they correlated with model predictions. The study found the following:

- There was no correlation between modeled mercury deposition and either soil concentrations or vegetation concentrations. At the Monticello plant, excess soil $\mathrm{Hg}$ was associated with soil characteristics with higher values near the lake. Vegetation concentration showed some correlation with soil concentrations having higher mercury in vegetation when the soil mercury

- Based on computer modeling, Hg deposition was primarily RGM with much lower deposition from elemental mercury. The total deposition within $50 \mathrm{Km}$ of the plant was predicted to be $4.2 \%$ of the total emitted. In the deposition, RGM is responsible for $98.7 \%$ of the total deposition, elemental mercury accounts for $1.1 \%$ and particulate mercury accounts for $0.2 \%$. Less than $1 \%$ of the elemental mercury emitted was predicted to deposit within $50 \mathrm{~km}$. 


\section{Table of Contents}

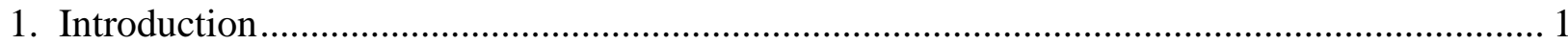

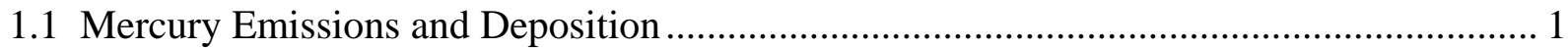

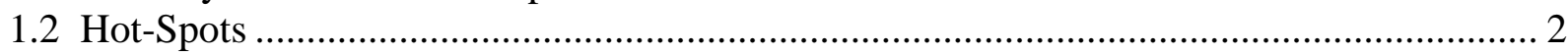

1.2.1 Defining a "Hot Spot." ................................................................................. 2

2. Evidence from the Literature for "Hot Spots" Near Mercury Emissions Sources ................ 4

3. Modeling Mercury Concentrations and Deposition around the Monticello Coal-Fired

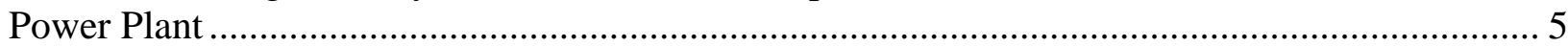

3.1 Deposition Model Paramaters ......................................................................... 6

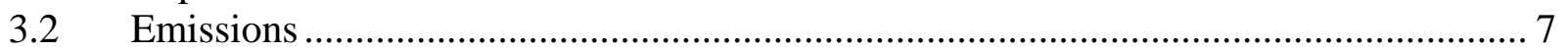

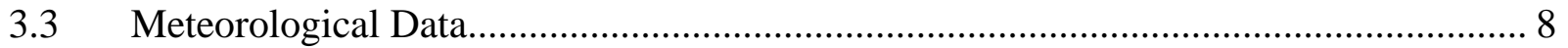

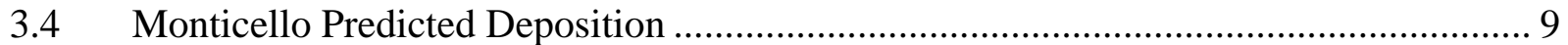

3.4.1 Summary of Deposition Modeling.................................................................. 15

4. Measuring Soil and Vegetation Concentrations of Mercury around the Monticello Coal-

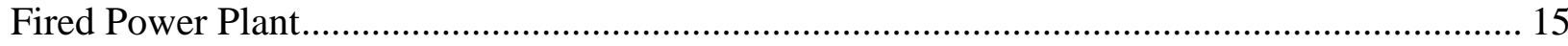

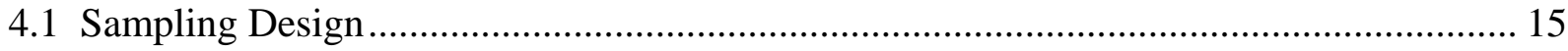

4.2 Mercury Analysis Methods and Quality Assurance ........................................... 16

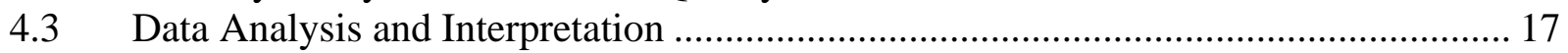

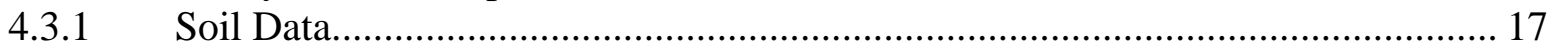

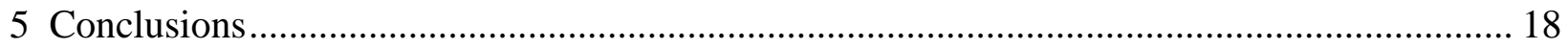

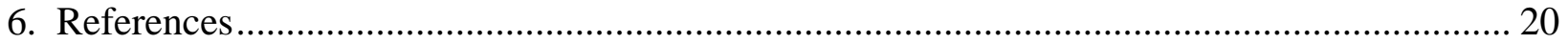

\section{List of Figures}

Figure 1 Direction and intensity of wind (Windrose) used for modeling deposition near the

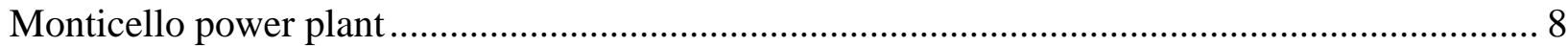

Figure 2 Precipitation Intensity and Direction used for modeling deposition around the Monticello Power Plant............................................................................................ 9

Figure 3 Predicted air concentrations $\left(\mathrm{ng} / \mathrm{m}^{3}\right.$ ) around the Monticello Power Plant (Plant

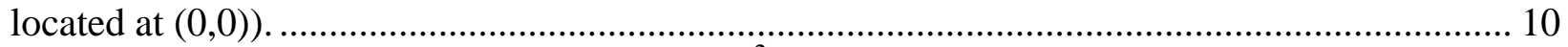

Figure 4 Total predicted wet deposition (ug/m²/yr) around the Monticello Power Plant........... 11 Figure 5 Total predicted dry deposition (ug/ $/ \mathrm{m}^{2} / \mathrm{yr}$ ) around the Monticello Power Plant........ 12 Figure 6 Predicted total deposition (ug/m²/yr) around the Monticello Power Plant.................. 13

Figure 7 Sample Location Map................................................................................... 16

Figure 8 a) Measured soil $\mathrm{Hg}$ (ng/g) concentrations with predicted deposition contours, and b) Measured vegetation $\mathrm{Hg}(\mathrm{ng} / \mathrm{g})$ concentrations near the Monticello Plant............................... 18

\section{List of Tables}

Table 1 Mercury emissions from the Monticello Tests. ....................................................... 7

Table 2: Monticello Plant yearly average maximum concentration and deposition values. ....... 14

Table 3 Monticello mercury deposition summary ........................................................... 14 


\section{Introduction}

Mercury is a neurotoxin that accumulates in the food chain and is therefore a health concern. Concentrations of mercury in the air are of little direct health concern. However, mercury in the air falls onto the Earth's surface through dry and wet deposition processes. This mercury can enter water bodies where a small percentage $(<10 \%)$ is transformed to methyl mercury. This chemical form of mercury readily enters the food chain and bioaccumulates. Upper trophic level fish can have mercury concentrations several orders of magnitude greater than that found in the water or sediment. As mercury accumulates in these organisms, ecological risks occur and potentially human health risks may occur through fish consumption.

\subsection{Mercury Emissions and Deposition}

Mercury is everywhere in the environment. Release of mercury to the air comes from natural and man-made processes. Natural releases of mercury comprise approximately two thirds of all emissions and arise from continual release from water, soils, and vegetation, as well as catastrophic events such as forest fires and volcanoes. Man-made releases of mercury arise from combustion, as well as other uses of mercury containing materials. Mercury emissions from coal-fired power plants in the United States are approximately 46 tons per year, roughly one third of all man-made sources. Thus, mercury emissions from coal-fired power plants account for 11 percent of all emissions in the U.S. Of the 150 tons per year of mercury emitted from man-made sources in the U.S., one third of this amount deposits within the U.S., while the remainder enters the global mercury cycle.

The Clean Air Interstate Rule (CAIR) and the Clean Air Mercury Rule (CAMR) as currently proposed by the U.S. Environmental Protection Agency (EPA) when fully implemented will lead to reduction in mercury emissions from coal-fired power plants by 70 percent to fifteen tons per year by 2018. The EPA estimates that mercury deposition would be reduced 8 percent on average in the Eastern United States. The CAMR permits cap-and-trade approach that requires the nationwide emissions to meet the prescribed level, but do not require controls on each individual power plant.

Mercury emissions from coal-fired power plants are categorized into three types, depending on how readily they deposit. These types are elemental mercury, reactive gaseous mercury, and particulate mercury. Elemental mercury is not soluble in water and enters the global mercury cycle. Reactive gaseous mercury and particulate mercury are soluble and readily deposit during precipitation events. These two forms of mercury deposit more readily under dry conditions than elemental mercury. The percentages of the three types of mercury emitted from a coal-fired power plant depend on the type of coal, plant characteristics, and pollution control technologies. Particulate and reactive gaseous mercury are removed easily by filters and other means, whereas elemental mercury is not. Based on 1999 data mercury emissions data collected from 81 coalfired power plants for the EPA, 54 percent of emissions are elemental mercury, 43 percent are reactive gaseous mercury, and 3 percent are particulate mercury. Modeling suggests that 50 percent of the reactive gaseous mercury will deposit within 300 miles of a large coal-fired power plant and less than 2 percent of elemental mercury will deposit over this distance. This is 
consistent with the observation that one third of the mercury emitted by man-made processes deposits within the borders of the U.S.

\subsection{Hot-Spots}

The currently proposed CAMR is based on the cap-and-trade principal that limits the total mercury emissions from all plants, but permits any single power plant to have emissions in excess of a specified rate for a cost. This has led to concerns that there may be hot-spots of mercury contamination near power plants. Partially because of this concern, many states have implemented, or are considering, state regulations that are stricter on mercury emissions than those in the CAMR.

Prior to determining if coal-fired power plants create mercury hot spots, we must define what is meant by a hot spot. Although the term "hot spot" appears frequently in the health and environmental literature, precise definitions do not. A "hot spot" is a region whose properties exceed those generally expected in the area. Although mercury emissions from a coal-fired power plant indeed constitute an emissions "hot spot," they do not necessarily constitute a human health risk hot spot. The primary health risk from mercury is to the developing fetus through consumption of fish by the mother. Therefore, to pose a health risk hot spot, a women of child-bearing age would have to routinely consume high-mercury fish from an affected water body for several months. This requires a substantial body of water, of the order of tens of square kilometers near the plant. In addition, it requires demonstration that the emissions from the coalfired power plant are responsible for the high levels of mercury in the fish. The EPA defines a utility hot spot as "a waterbody that is a source of consumable fish with Methylmercury tissue concentrations, attributable solely to utilities, greater than the EPA's Methylmercury water quality criterion of $0.3 \mathrm{mg} / \mathrm{kg}$." They also claim that under CAMR, there will be no utility hot spots. The EPA definition is difficult to prove or disprove because it would require knowledge of the levels of methylmercury in fish prior to the start of coal power use in the region. Thus, for the purposes of this discussion, a hot spot is a region of several square kilometers in which mercury concentrations are 2 to 3 times the expected value for the area.

\subsubsection{Defining a "Hot Spot."}

Although the term "hot spot" appears frequently in the health and environmental literature, precise definitions do not. Generally speaking, a "hot spot" is a spatial anomaly, i.e., a location whose properties exceed those generally expected in the area. In statistical terms, a hot spot is an location whose properties exceed more than about 2 or 3 standard deviations above the relevant mean. Methods to statistically define a hot spot for metals in soils generally compare the data to a log normal distribution and look for variations between the two (Tobias, 1997). Some authors have simply defined "hot spots" as the highest observed values; for example, Worm et al. (2003) found a range of diversities in ocean predator species of less than one order of magnitude, among which the highest groups were termed "hot spots". Lebret et al. (2000) used the term to refer to locations where the ambient air quality standard for $\mathrm{NO}_{2}$ is routinely exceeded. These two examples of "hot spots" would not meet the statistical definition.

However, the expected ranges of environmental concentrations depend heavily on the "natural" or background values and on the length of the measurement period (i.e., the averaging time). In many cases, environmental concentrations are log-normally distributed (skewed towards high 
values), so that the distribution is best described by the log-mean and the geometric standard deviation (GSD). As an example, Lu et al. (2005) studied the distribution of the polycyclic aromatic hydrocarbon naphthalene in Southern California and found a large range of values, in part because there is little or no natural background. The log-mean and GSD for 13 one- to twomonth averages were $227 \mathrm{ng} / \mathrm{m}^{3}$ and 1.57, leading to an expected range of a factor of 6 . However, for 16 four-day averages in other locations, these values were $269 \mathrm{ng} / \mathrm{m}^{3}$ and 3.12 , leading to an expected range of a factor of 94. In both of these distributions, the top 3 or 4 values appear to be outliers and thus bona fide "hot spots", since deleting them reduces the range of the distribution by about a factor of 2 .

While small-scale transient hot spots may be a valid concern for inhalation exposures, the situation with mercury is quite different. The exposure pathway is through diet, and the relevant human exposure times relate to the development of the fetus and are of the order of months. Although a large point-source of $\mathrm{Hg}$ indeed constitutes an emission "hot spot", it does not constitute a fetal exposure hot spot. In addition to the substantial global background in $\mathrm{Hg}$ air concentrations and deposition, the following processes act to smooth out spatial anomalies:

- Atmospheric variability, including winds and precipitation.

- Re-emission of mercury from vegetation.

- Terrestrial leaching and washout in transferring watershed deposits into water bodies.

- Aquatic mixing within water bodies.

- Spatial and temporal variability in biomagnification processes.

- Variability among fish species.

Only atmospheric variability is included in the models that may be used to define deposition "hot spots." The other processes involve spatial variability, especially with regard to mixing within the receiving waters, for which the size of the water body may be key. In order for a local $\mathrm{Hg}$ deposit to pose a risk to a developing fetus, its mother must routinely consume high- $\mathrm{Hg}$ fish from an affected water body for several months, probably at the rate of 2 or 3 meals per day. While this scenario is unlikely in any event, it also requires a substantial fish population, which requires a substantial body of water, say of the order of tens of square $\mathrm{km}$.

Many empirical findings concerning $\mathrm{Hg}$ are subject to experimental error, which may be considerable in some cases. Accordingly, statistical methods may be required to gain an understanding of the data. They include averaging, correlation, and linear regression, using established relationships to try to reduce experimental variability. In all cases, "statistical significance" implies a 95\% probability that the finding is not due to chance alone, denoted as "p $<0.05$ ".

This study examined the possibility that coal-fired power plants act as local sources leading to mercury "hot spots", using two types of evidence.. First, the world-wide literature was searched for reports of deposition around mercury sources, including coal-fired power plants. Second, soil samples from around two mid-sized U.S. coal-fired power plants were collected and analyzed for evidence of "hot spots" and for correlation with model predictions of deposition. 


\section{Evidence from the Literature for "Hot Spots" Near Mercury Emissions Sources}

The rationale for regulating air emissions of mercury from U.S. coal-fired power plants largely depends on mathematical dispersion modeling, including the atmospheric chemistry processes that affect the partitioning of $\mathrm{Hg}$ emissions into elemental $(\mathrm{Hg}(0))$ and the reactive gaseous mercury ( $\mathrm{RGM}$ or $\mathrm{Hg}^{+2}$ ) forms that may deposit more rapidly near sources. Mercury is a global pollutant and therefore, modeling estimates are often based on a large scale. Fine scale, $(<20$ $\mathrm{km}$ ) modeling of point sources is not performed often. In addition, there is evidence (Edgerton 2004, EPRI 2004) that reactive gaseous mercury in coal-fired power plant plumes quickly reduces to elemental mercury. This chemical process, which would greatly affect the amount of local deposition however, the corresponding chemical reactions are not included in the available local mercury deposition models. As a result, field data are necessary to check for the existence of mercury "hot spots" near coal-fired power plants.

Literature reviews examined the evidence for deposition around local sources including coalfired power plants (Lipfert et al. 2004, Sullivan, et al., 2005) . The extant experimental data are considered at three spatial scales: local $(<30 \mathrm{~km})$, regional $(<\sim 300 \mathrm{~km})$, and national (multistate data). The reviews covered data on mercury content in soils, sediments, precipitation, and fish and mercury deposition rates in precipitation. The reviews (Lipfert et al. 2004, Sullivan, et al. 2005) lead to the overall conclusion that atmospheric deposition of $\mathrm{Hg}$ is affected by emissions from coal-fired power plants. However, because of the numerous assumptions required and the use of simplistic models, it is not possible to describe these relationships accurately based on these findings. Nevertheless, coal-fired plants seem to contribute less than $10 \%$ of total $\mathrm{Hg}$ deposition on a national scale, and the resulting effects on fish $\mathrm{Hg}$ appear to be even smaller. In contrast, there is strong evidence of enhanced local deposition within $3 \mathrm{~km}$ of the chlor-alkali plants, with elevated soil concentrations and estimated deposition rates of 10 times background. (Lodenius, 1998, Biester et al. 2002, Biester et al. 2002a, Sensen et al. 2002, Southworth et. al. 2004). Evidence for enhanced deposition near a calcining plant also exists (Abbott et al. 2003, Susong et al. 2003).

Reliable quantitative understanding of the processes of mercury emissions, deposition, and translocation through the food chain remains elusive. Complex atmospheric chemistry and dispersion models are required to predict precise concentration and deposition contributions, and aquatic process models are required to predict effects on fish. However, there is uncertainty in all of these predictions, especially with regard to the fate of reactive gaseous mercury in coalfired power plant plumes. Therefore, at this time, the most reliable way to understand the impacts of coal-fired power plants on $\mathrm{Hg}$ deposition is based on empirical data. In terms of excesses over background, local soil concentration $\mathrm{Hg}$ increments are around 30\%-60\%; sediment increments are 18-30\% (Anderson et al. 1977, Menounou et. al. 2003) and wet deposition increments are around 11-12\% (Lipfert et. al., 2004). Soil and sediment effects are necessarily cumulative, in contrast to wet deposition. Based on the empirical finding (Lipfert et al., 2004) that fish $\mathrm{Hg}$ is proportional to the square root of wet deposition (after controlling for water chemistry), then the contribution of coal-fired power plants to fish $\mathrm{Hg}$ would be about 5$6 \%$. Local differences in water chemistry may also help explain the absence of a relationship between state-level fish concentrations and wet deposition levels; it is possible that the absence of local impacts on fish at the Kincaid power plant (Anderson, et al. 1977) was related to water chemistry. 


\section{Modeling Mercury Concentrations and Deposition around the Monticello Coal- Fired Power Plant}

Studies of soils, sediments, and wet deposition around coal plants typically find some evidence of enhanced deposition; however, the impact and statistical significance of the results is generally weak. Many of the coal plant studies (Klein et al. 1973, Anderson et al. 1977, Crockett et al. 1979, Kotnik, et al. 2000) were conducted in the 1970's when emission rates were higher due to fewer pollution controls and the use of coals with higher $\mathrm{Hg}$ content. In addition, these studies did not attempt to correlate modeled deposition with measured soil concentrations.

The Hg deposition models are based on a number of assumptions and hence there is uncertainty in the predicted deposition rates. A key assumption in the models is that the mixture of reactive gaseous mercury (RGM) to elemental mercury $\operatorname{Hg}(0)$ is constant in the exhaust plume. However, recent experiments suggest that reactive gaseous mercury converts to $\operatorname{Hg}(0)$ quickly (Edgerton et al, 2004, Laudal et al, 2004). If the hypothesis is correct, then local impact of coalfired power plants will be greatly reduced, since $\mathrm{Hg}(0)$ does not deposit as quickly as reactive gaseous mercury. In studies conducted at two sites in Georgia and one in Florida (Edgerton et al., 2004), plumes from power plants were tracked using the sulfur dioxide emitted from the stacks as a tracer. For 31 plume touchdown events, mercury speciation at the ground level monitoring station, which was $14-150 \mathrm{~km}$ away from the power plants, showed levels of reactive gaseous mercury around $14-23 \%$ as compared to $53-75 \%$ when emitted from the stacks. Wet deposition cannot account for this reduction, as rain did not occur over the period of travel time from emission to the monitoring point ( $<$ a few hours). Dry deposition effects were also minimized by collecting samples early in the day when dry deposition is minimized. Studies of airborne mercury speciation in power plant plumes also showed a reduction in the percentage of reactive gaseous mercury (Laudal, 2004). An airplane was flown through the plume from the Pleasant Prairie power plant in southern Wisconsin at distances of less than $1 / 4$ mile, 5 miles, and 10 miles from the stack. Measurements of the stack gas showed that releases were $67 \% \mathrm{Hg}(0)$ and $33 \% \mathrm{Hg}^{+2}$. Less than $1 / 4$ mile from the stack, the mercury speciation changed to $83 \% \mathrm{Hg}(0)$ and by five miles approximately $88 \%$ of the mercury was in elemental form, $\operatorname{Hg}(0)$. This percentage of $\mathrm{Hg}(0)$ was maintained at the 10 mile distance. While there are uncertainties associated with measuring mercury in the plume from an aircraft, these results are consistent with the findings on the ground (Edgerton et. al, 2004) and eliminate differential deposition as the cause for the depletion of $\mathrm{Hg}^{+2}$.

The extant computer modeling suggests that increased local deposition will occur on a local (2 to $10 \mathrm{~km}$ ) to regional scale $(20$ to $50 \mathrm{~km}$ ) with local increases a small percentage of background deposition on the regional scale. (EPA, 1997, Sullivan, et al., 2001, Sullivan et al., 2003). The amount of deposition depends upon many factors including emission rate, chemical form of mercury emitted (with reactive gaseous mercury depositing more readily than elemental mercury), other emission characteristics (stack height, exhaust temperature, etc), and meteorological conditions. Modeling suggests that wet deposition will lead to the highest deposition rates and that these will occurwithin a few $\mathrm{km}$ of the plant. The rates of dry deposition are are predicted to be less than for wet deposition, but they apply to a much greater area (Sullivan et al., 2003). Therefore, on the regional scale, dry deposition may be more important than wet. However, it is quite difficult to measure dry deposition of $\mathrm{Hg}$ directly. 
To further understand the impacts of local deposition, soil and vegetation samples were collected around the Monticello coal-fired power plant and analyzed for mercury. Previous studies examined soil and vegetation around a mid-size plant in the midwest that burns locally mined lignite. This site will be referred to as Plant A for reasons of confidentiality. The second plant is the Kincaid power plant located southeast of Springfield IL that was studied in the 1970's (Anderson et al., 1977). This study combines modeling of mercury deposition patterns with soil and vegetation mercury measurements. The deposition model used emissions data, meteorological conditions, and plant data to define sample locations likely to exhibit deposition in excess of background that can be attributed to the power plant. The data are evaulated looking for revidence of 'hot spots'. Comparisons between the data and the models were made to test the validity of the model.

\subsection{Deposition Model Paramaters}

The local atmospheric transport of mercury released from the coal-fired power plants was studied to estimate the local impacts of mercury deposition. The Industrial Source Code (ISCST3) Short Term air dispersion model was used to model these processes (EPA, 1995). This code is an updated version of the computer code used by the U.S. Environmental Protection Agency to examine local deposition from combustion sources in their report to Congress in 1998 (EPA, 1997).

The basis of the ISCST3 model is the straight-line, steady-state Gaussian plume equation, which is used with some modifications to model simple point source emissions from stacks and emissions from stacks that experience the effects of aerodynamic downwash due to nearby buildings. Emission sources are categorized into four basic types of sources, i.e., point sources, volume sources, area sources, and open pit sources. Point sources were used to model the emissions from the stacks of the coal fired power plants. ISCST3 has models to simulate wet and dry deposition of mercury and depletion of the plume due to deposition. The algorithms used to in ISCST3 are described elsewhere in detail (EPA, 1995).

The ISC Short Term model accepts hourly meteorological data records to define the conditions for plume rise, transport, diffusion, and deposition. The model estimates the concentration or deposition value for each source and receptor combination for each hour of input meteorology, and calculates user-selected short-term averages. For deposition values, the dry deposition flux, the wet deposition flux, or the total deposition flux may be estimated. The total deposition flux is simply the sum of the dry and wet deposition fluxes at a particular receptor location.

Emissions data from the Monticello power plant was used to represent the source term. Meteorological data from nearby weather stations was used to simulate typical weather patterns. This approach was selected because environmental monitoring studies suggest that measured mercury levels in environmental media and biota may be elevated in areas round stationary combustion sources that emit mercury.

Modeling deposition requires three key sets of parameters, source emissions ratios, meteorological data, and deposition parameters. The following sections describe each of these in detail. 


\subsection{Emissions}

Two types of mercury species occur in the emissions and they behave quite differently once emitted from the stack. Elemental mercury, $\operatorname{Hg}(0)$, due to its high vapor pressure and low water solubility, is not expected to deposit close to the facility. In contrast, reactive gaseous mercury (RGM), $\mathrm{Hg}^{+2}$, will react with other impurities in the air that are readily accommodated in rain and therefore, will deposit in greater quantities closer to the emission sources. In addition, RGM will also undergo dry deposition at a much higher rate than elemental mercury.

At the point of stack emission and during atmospheric transport, mercury can also become bound to particulate matter. This form of mercury, $\operatorname{Hg}(\mathrm{p})$, can be removed from the atmosphere by both wet deposition (precipitation scavenging) and dry deposition (gravitational settling, Brownian diffusion).

In 1999, the EPA requested information from over 100 coal fired units on the emissions of mercury. Subsequently, testing was performed to measure the release of three types of mercury (elemental, RGM, and particulate-bound) from the exhaust stacks of these plants. For this analysis, the data the Monticello Plant in Monticello, TX (Table 1) was used as the emissions source term.

Table 1 Mercury emissions from the Monticello Tests.

\begin{tabular}{|l|c|c|c|c|c|c|}
\hline Unit & Test 1 & Test 2 & Test 3 & Test 4 & Test 5 & Test 6 \\
\hline $\mathrm{Hg}(0)(\mathrm{g} / \mathrm{yr})$ & 288125 & 252739 & 542246 & 556974 & 603532 & 258856 \\
\hline $\mathrm{Hg}(+2)(\mathrm{g} / \mathrm{yr})$ & 1346488 & 1318804 & 170297 & 123022 & 10479 & 524072 \\
\hline $\mathrm{Hg}(\mathrm{p})(\mathrm{g} / \mathrm{yr})$ & 1267 & 1900 & 5610 & 5781 & 4257 & 2780 \\
\hline Total $\mathrm{Hg}(\mathrm{g} / \mathrm{s})$ & 0.052 & 0.050 & 0.023 & 0.022 & 0.020 & 0.017 \\
\hline Fraction $\mathrm{Hg}(0)$ & 0.18 & 0.16 & 0.75 & 0.81 & 0.97 & 0.04 \\
\hline Fraction $\mathrm{Hg}(+2)$ & 0.82 & 0.84 & 0.24 & 0.18 & 0.02 & 0.95 \\
\hline Fraction $\mathrm{Hg}(\mathrm{p})$ & 0.0008 & 0.0012 & 0.0078 & 0.0084 & 0.0069 & 0.005 \\
\hline
\end{tabular}

Tests 1, 2 and 6 were conducted on unit 1 . While tests 3,4, and 5 were from Unit 3 . There is a major difference between unit 1 and unit 3 emissions with Unit 1 emitting predominantly $\mathrm{Hg}(+2)$ while unit 3 emits primarily $\mathrm{Hg}(0)$. The difference reflects the pollution control devices on Unit 3. Both units emit only a small fraction of $\mathrm{Hg}(\mathrm{p})$.

The fraction of the 3 types of mercury weighted by total emissions during the test periods is:

$$
\begin{aligned}
& \mathrm{Hg}(0)=39.2 \% \\
& \mathrm{Hg}(+2)=60.4 \%, \text { and } \\
& \mathrm{Hg}(\mathrm{p})=0.3 \%
\end{aligned}
$$

Total mercury emissions from the Monticello power station were $954.5 \mathrm{~kg}(0.03 \mathrm{~g} / \mathrm{s})$ in 1999 . Monticello is typically among the top five plants in total mercury emissions in the U.S. In 1999, the year of the data collection it was the plant with the highest mercury emissions in the U.S. Using the fractional release rate from the test data, the release rate for each mercury category is:

Emissions (g/s)
$\operatorname{Hg}(0)-$
0.012 
$\mathrm{Hg}(+2)-\quad 0.018$

$\operatorname{Hg}(\mathrm{p})-\quad 0.000091$

\subsection{Meteorological Data}

The Monticello plant is located in Monticello, Tx about 120 miles east of Dallas, Tx.

Meteorological data from 1990 taken in Dallas was used as the basis for deposition modeling. The wind is almost always from due north or south, predominantly from the south $(20 \%$ of the time), Figure 1. Approximately $10 \%$ of the time the wind is out of the north. In contrast, precipitation events occur most frequently when the wind is out of the north, Figure 2. South easterly winds also account for substantial rainfall. Rainfall occurred approximately $4 \%$ of the time with a total amount of $80 \mathrm{~cm}$.

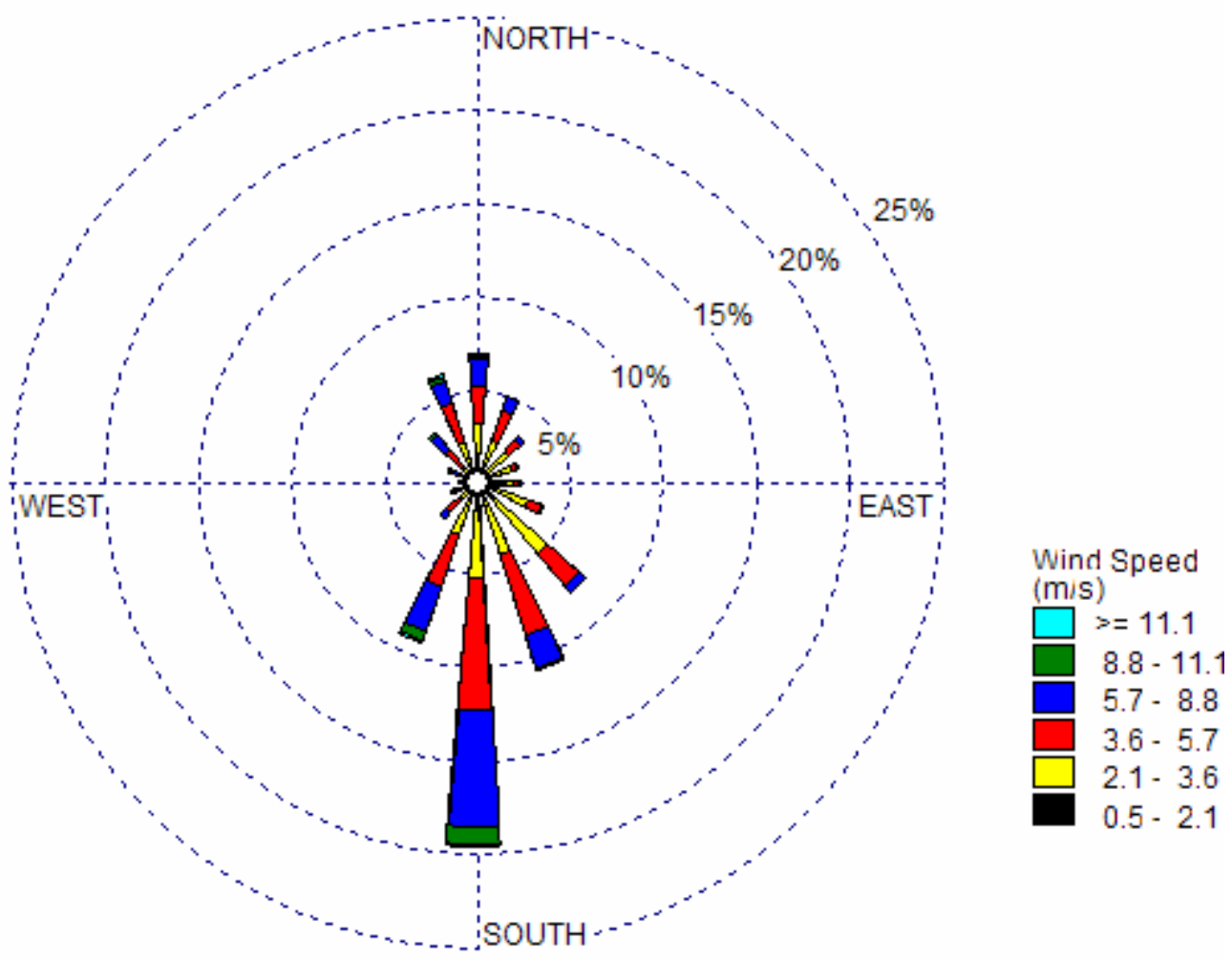

Figure 1 Direction and intensity of wind (Windrose) used for modeling deposition near the Monticello power plant 


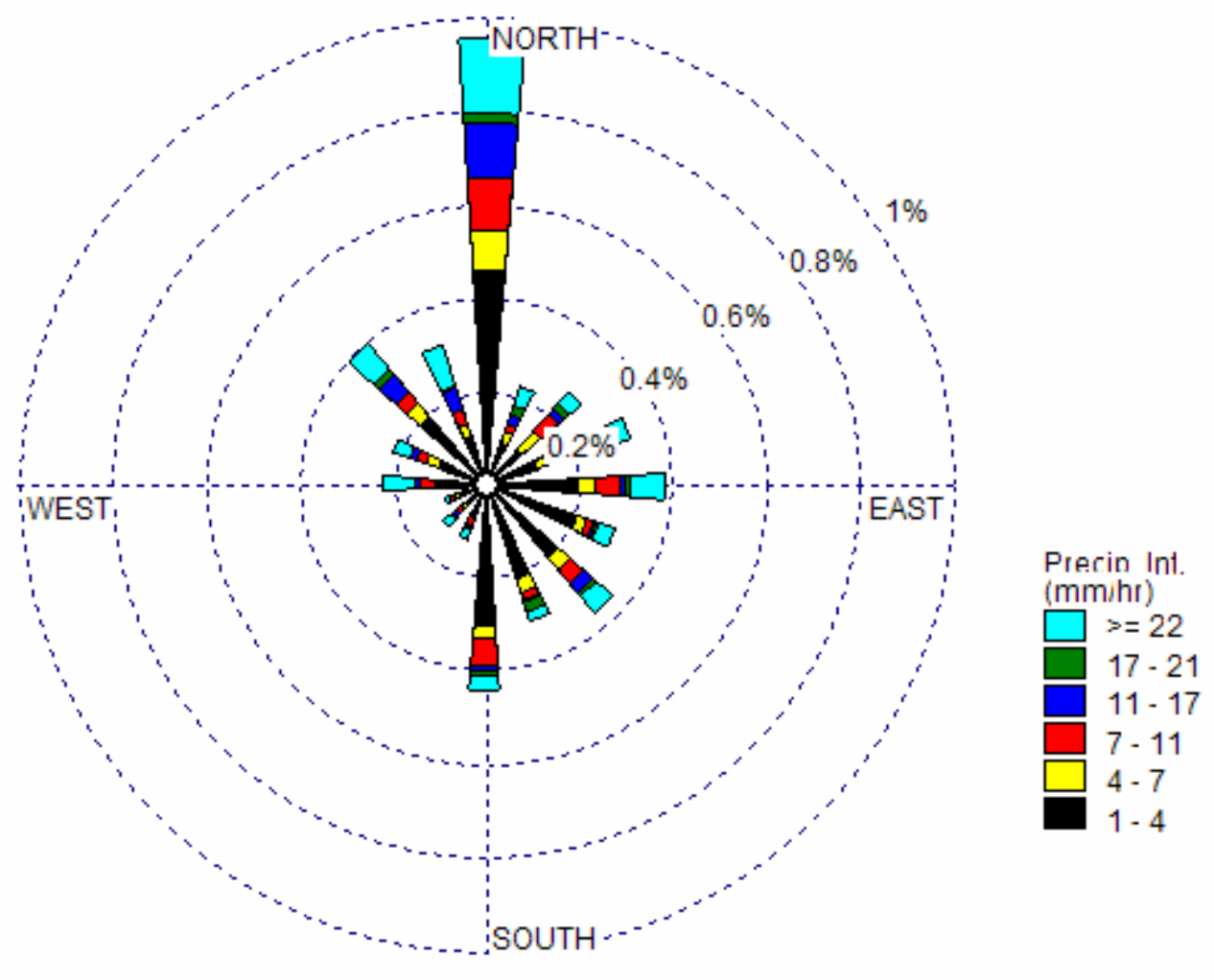

Figure 2 Precipitation Intensity and Direction used for modeling deposition around the Monticello Power Plant.

\subsection{Monticello Predicted Deposition}

The above data along with data on the plant size and deposition parameters (Sullivan, 2002) were used to predict the amount of local deposition around the Monticello power plant. In the simulations the concentration of mercury in air $\left(\mathrm{ng} / \mathrm{m}^{3}\right)$, wet deposition $\left(\mu \mathrm{g} / \mathrm{m}^{2} / \mathrm{yr}\right)$ and dry deposition $\left(\mu \mathrm{g} / \mathrm{m}^{2} / \mathrm{yr}\right)$ were computed on a $1 \mathrm{Km}$ grid centered around the plant. Air concentrations were available in terms of a yearly average value as well as peak values over a 24 hour period. Simulations were carried out for a minimum of $25 \mathrm{Km}$ in the downwind direction.

Local deposition modeling was performed to indicate the increase in concentrations and deposition over natural background. Concentrations of mercury in air have been determined from a number of locations. Typical values are around $1-4 \mathrm{ng} / \mathrm{m}^{3}$ in rural areas and $10-50$ $\mathrm{ng} / \mathrm{m}^{3}$ in urban areas. In EPA's report to Congress (EPA, $1998 \mathrm{c}$ ) a value of $1.7 \mathrm{ng} / \mathrm{m}^{3}$ was the average mercury level away from sources. Wet deposition is being measured throughout the country through the Mercury Deposition Network. Deposition rates range from $5-25 \mathrm{ug} / \mathrm{m}^{2} / \mathrm{yr}$. At the MDN station in Longview Texas, approximately 60 miles southeast of Monticello, 
between 1998 and 2005 the range is 8 to $15.710-16 \mathrm{ug} / \mathrm{m}^{2} / \mathrm{yr}$ with an average of $11.8 \mathrm{ug} / \mathrm{m}^{2} / \mathrm{yr}$. Dry deposition is not well understood but estimates indicate that it should be in the range of 50 to $100 \%$ of wet deposition. For a comparison basis, this study will use an air concentration value of $1.7 \mathrm{ng} / \mathrm{m}^{3}$, wet deposition of $12 \mathrm{ug} / \mathrm{m}^{2} / \mathrm{yr}$, dry deposition of $12 \mathrm{ug} / \mathrm{m}^{2} / \mathrm{yr}$ and a total deposition of $24 \mathrm{ug} / \mathrm{m}^{2} / \mathrm{yr}$.

Local deposition modeling was performed for the Monticello plant. Figure 3 presents the predicted yearly average concentration data around the plant. Concentrations peak to the north of the plant consistent with the prevailing southerly winds, Figure 2 . The peak value is 0.04 $\mathrm{ng} / \mathrm{m}^{3}$, less than $3 \%$ of the expected background concentration, $1.7 \mathrm{ng} / \mathrm{m}^{3}$. However, the amount of RGM is $0.022 \mathrm{ng} / \mathrm{m}^{3}$ which is approximately the same as the expected background level of RGM. The maximum daily average concentration was $0.58 \mathrm{ng} / \mathrm{m}^{3}$, approximately $34 \%$ of the expected background. This indicates that even in the immediate vicinity of the power plant with the largest emissions in the US, the increase in air concentrations are only a fraction of background levels.

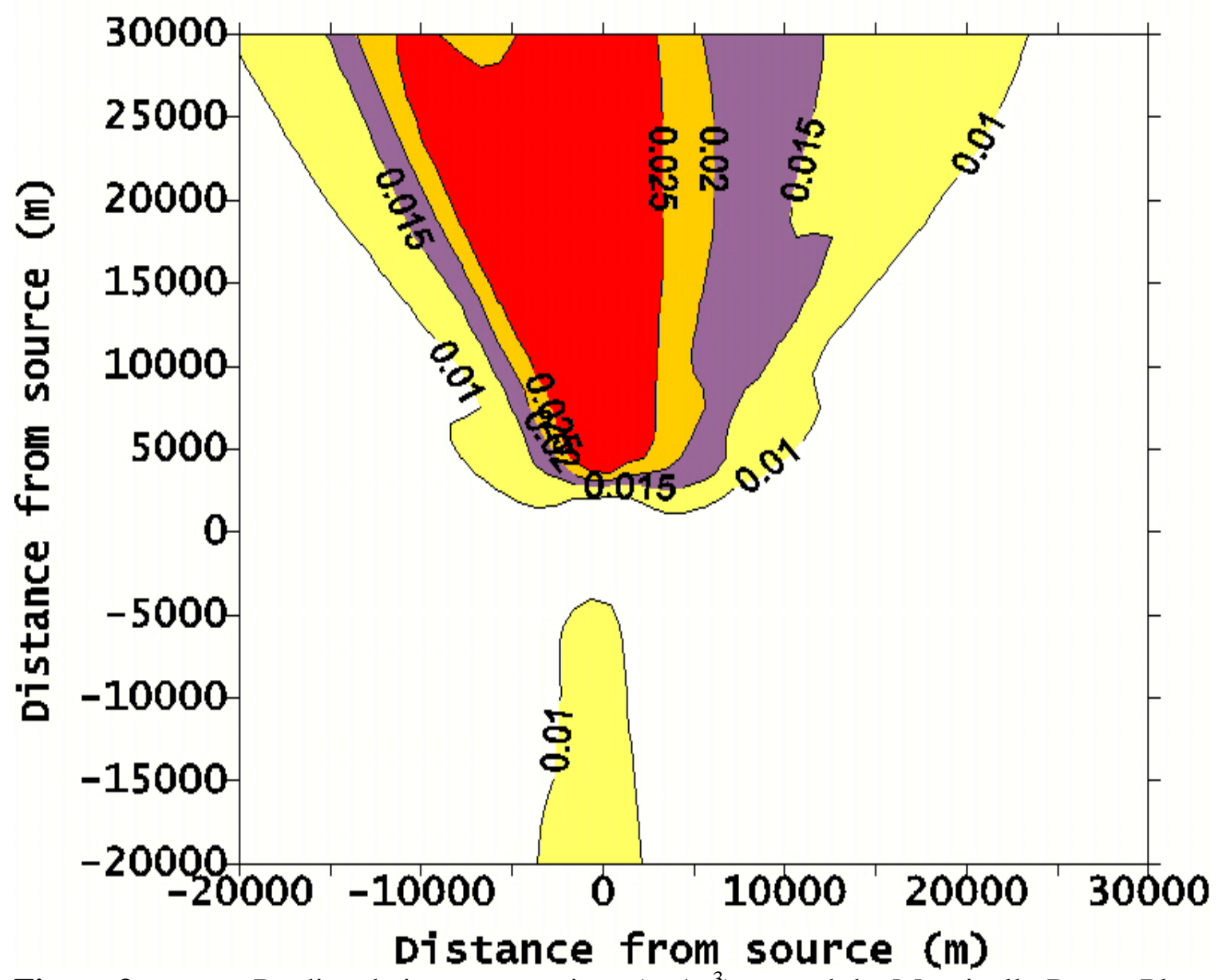

Figure 3 Predicted air concentrations $\left(\mathrm{ng} / \mathrm{m}^{3}\right)$ around the Monticello Power Plant (Plant located at $(0,0))$.

Figure 4 presents the predicted total wet deposition of mercury around the Monticello Power Plant. Over $98 \%$ of the deposition arises from reactive gaseous mercury. This is due to the large fraction of RGM $(60 \%)$ in the emissions and the large deposition parameters relative to elemental mercury. Due to the wind flow being almost exclusively in the north-south direction, 
the wet deposition is located along this axis. The large amount of RGM in the emissions leads to high predicted deposition rates. Wet deposition is predicted to be greater than $40 \mathrm{ug} / \mathrm{m}^{2} / \mathrm{yr}(>3$ times background) for a distance of five kilometers from the plant in both the north and south directions. The predicted region with excess deposition of $5 \mathrm{ug} / \mathrm{m}^{2} / \mathrm{yr}$ extends more than $40 \mathrm{Km}$ along the north-south axis.

\section{Monticello Power Station \\ Total Wet deposition $\left(\mathrm{ug} / \mathrm{m}^{\wedge} 2 / \mathrm{yr}\right)$}

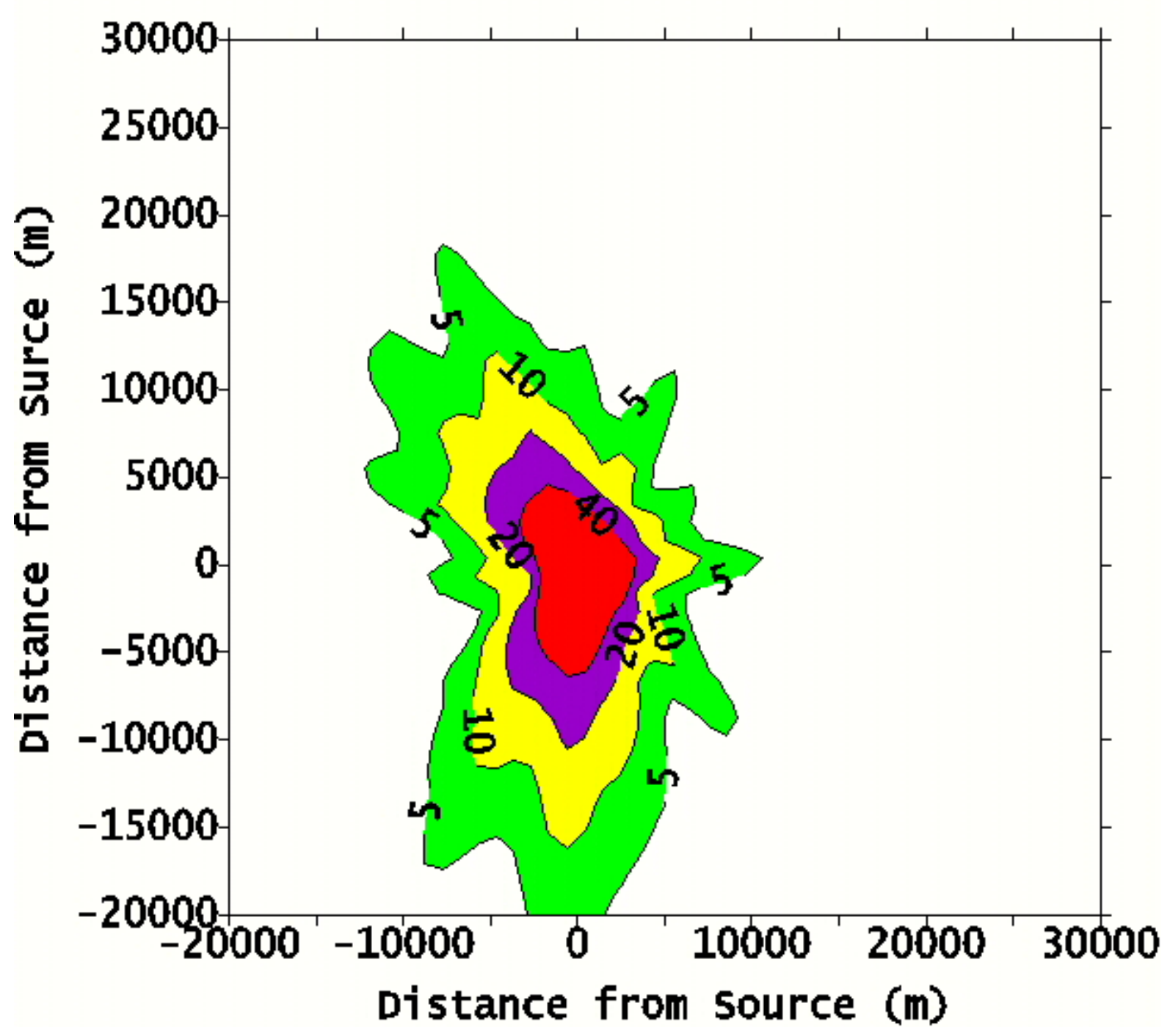

Figure 4 Total predicted wet deposition (ug/m²/yr) around the Monticello Power Plant

Figure 5 presents the predicted dry deposition pattern around the Monticello power plant. Again, due to the different dry deposition velocities, RGM contributes approximately $98 \%$ of the total deposition even though it is only $60 \%$ of emissions. The deposition pattern peaks to the north of the facility consistent with the prevailing winds. Total deposition rates are in excess of the estimated background dry deposition rate of $10 \mathrm{ug} / \mathrm{m}^{2} / \mathrm{yr}$ for more than $30 \mathrm{Km}$ from the plant. Subsequent modeling showed that the region of dry deposition in excess of $10 \mathrm{ug} / \mathrm{m}^{2} / \mathrm{yr}$ was 
contained within $50 \mathrm{Km}$ of the plant. The fact that the peak is away from the plant results from the emission at elevated temperature and height.

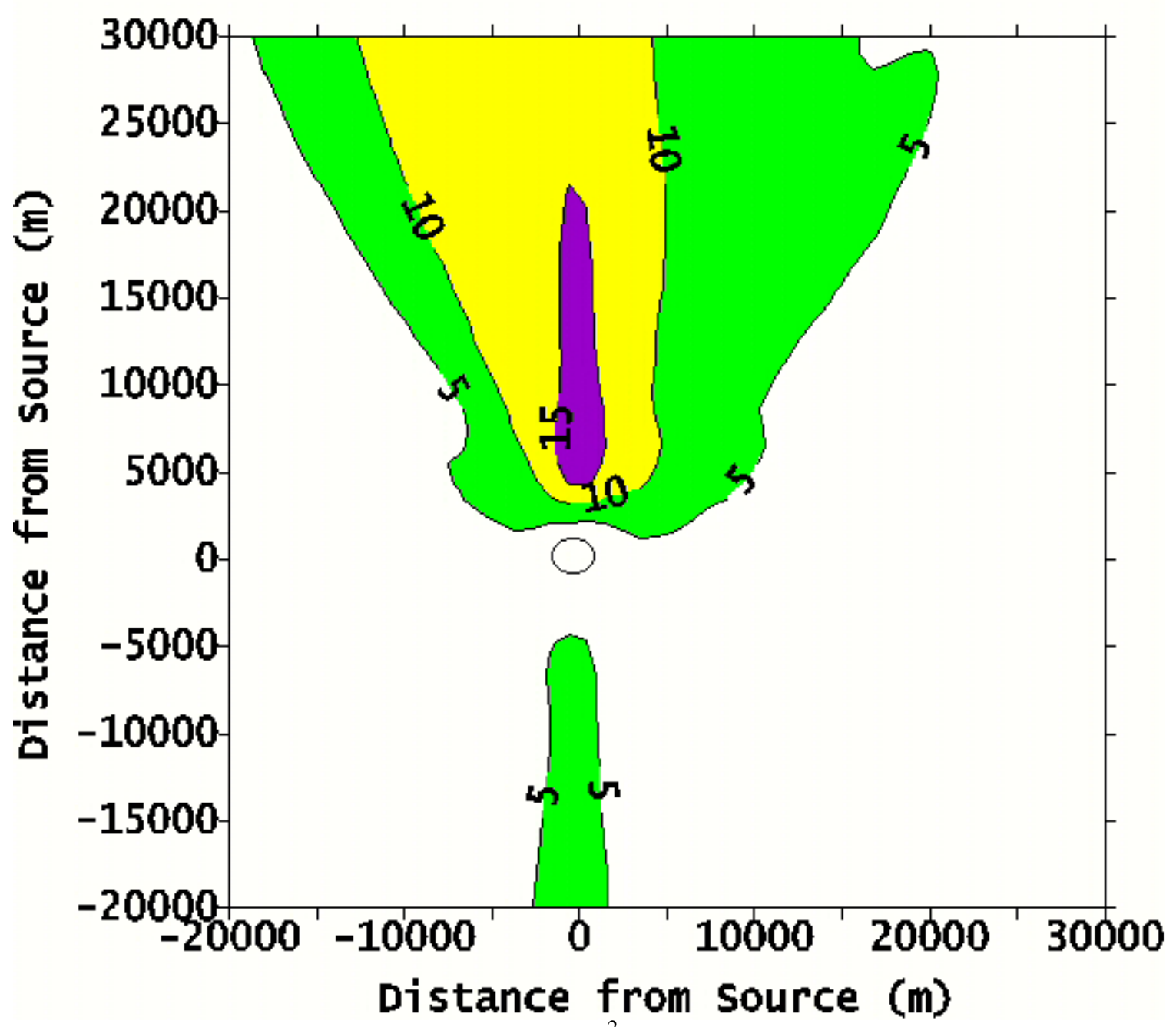

Figure 5 Total predicted dry deposition (ug/m²/yr) around the Monticello Power Plant.

Figure 6 shows the combination of dry and wet deposition around the Monticello power plant. The deposition is peaked along the north-south axis, which is the direction of wind flow. 


\section{Montlcello Power Statlon Predicted $\mathrm{Hg}$ deposition (ug/m2/yr) contours}

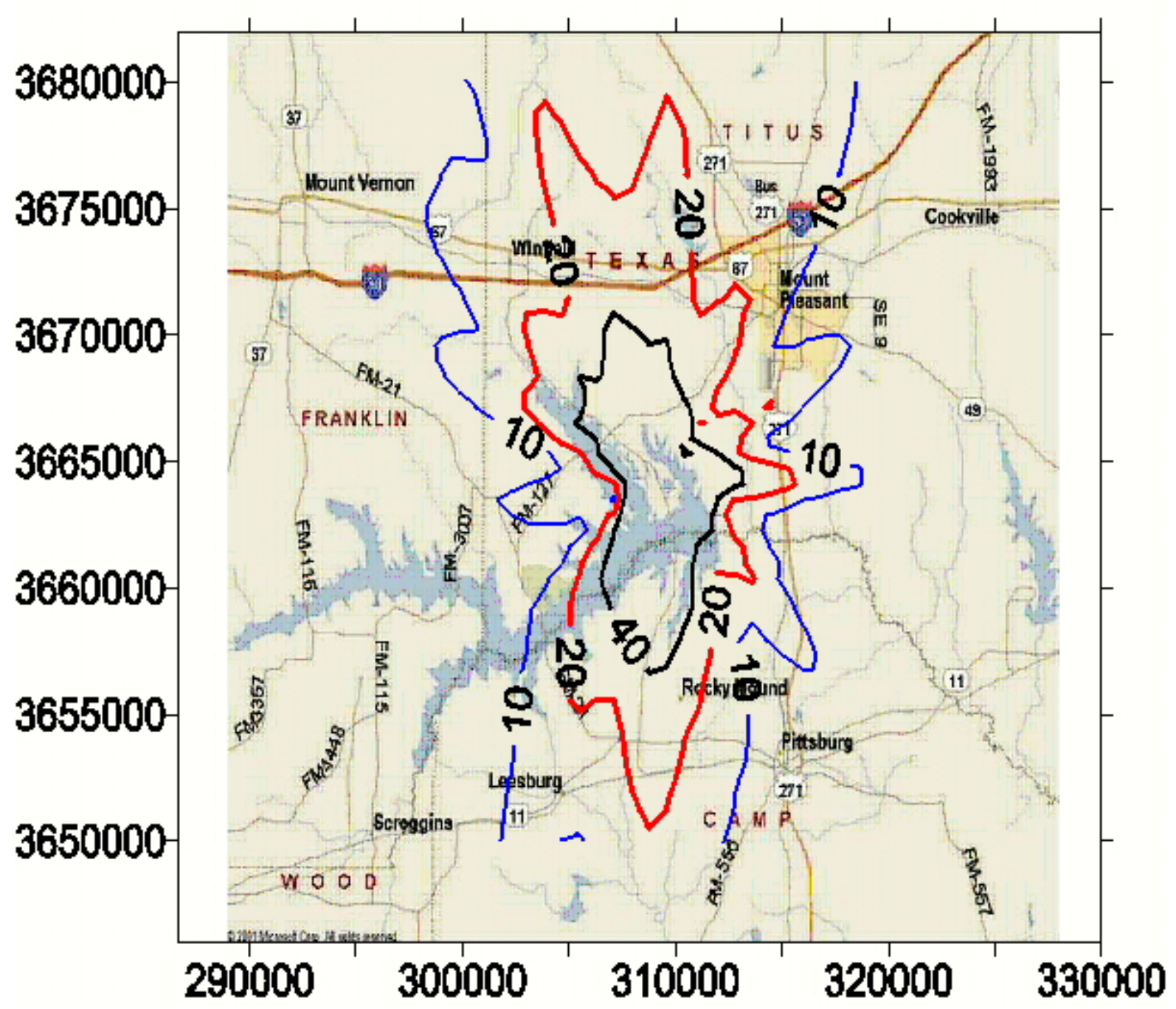

Figure 6 Predicted total deposition (ug/ $\mathrm{m}^{2} / \mathrm{yr}$ ) around the Monticello Power Plant.

Table 2 summarizes the predicted total mass deposited and the average deposition rate over the modeled area around the Monticello plant for each of the three forms of mercury. The total mass deposited over the $30 \mathrm{~km}$ modeled domain is predicted to 23400 grams or $2.5 \%$ of the total emitted. Increasing the distance to a $50 \mathrm{~km}$ radius around the plant did not change the predicted wet deposition. However, the dry deposition mass increased by a factor of 3 to $29100 \mathrm{~g}$. The total deposition within $50 \mathrm{Km}$ of the plant was 40100 grams, $4.2 \%$ of the total emitted. This indicates that the vast majority of mercury emitted from the Monticello plant is not deposited within $50 \mathrm{~km}$ of the plant. In the emissions, elemental mercury accounts for $40 \%$ of the mass, RGM accounts for $60 \%$ and particulate mercury accounts for $0.3 \%$. In the deposition, RGM is responsible for $98.7 \%$ of the total deposition, elemental mercury accounts for $1.1 \%$ and particulate mercury accounts for $0.2 \%$. Their fractional deposition rate (mass deposited over the $50 \mathrm{~km}$ modeled domain divided by the mass emitted from the plant) was around 4\%, while less than $0.07 \%$ of the elemental mercury deposited locally. Although, the peak deposition rates are 
much higher for wet than dry deposition, the total mass deposited by each mechanism is approximately the same. Over the $50 \times 50 \mathrm{~km}$ rectangular area of the modeled domain, the average deposition rates for wet and dry deposition are similar and around $4.5 \mathrm{ug} / \mathrm{m}^{2} / \mathrm{yr}$. The area average deposition rate over this area, $9.30 \mathrm{ug} / \mathrm{m}^{2} / \mathrm{yr}$ is approximately $39 \%$ of that expected from background $\left(24 \mathrm{ug} / \mathrm{m}^{2} / \mathrm{yr}\right)$. However, regions of this area along the prevailing wind direction were in excess of $20 \mathrm{ug} / \mathrm{m}^{2} / \mathrm{yr}$. Within $5 \mathrm{Km}$ of the plant in the prevailing wind direction, predicted deposition exceeded $40 \mathrm{ug} / \mathrm{m}^{2} / \mathrm{yr}$, or almost twice the expected background. The Monticello plant is expected to be an upper bound on deposition from coal fired power plants due to the large emission rate (highest in the US, almost $2 \%$ of total US emissions), high fraction of RGM (60\%, US average 34\%) and meteorological conditions (wind almost exclusively from the South).

Table 2: Monticello Plant yearly average maximum concentration and deposition values.

\begin{tabular}{|l|l|l|l|}
\hline & $\mathrm{Hg}(0)$ & $\mathrm{Hg}(+2)$ & $\mathrm{Hg}(\mathrm{p})$ \\
\hline Particulate $\left(\mathrm{Hg}_{\mathrm{p}}\right)$ & & & \\
\hline Concentration $\left(\mathrm{ng} / \mathrm{m}^{3}\right)$ & & & $1.410^{-4}$ \\
\hline Max Wet Deposition $\left(\mathrm{ug} / \mathrm{m}^{2} / \mathrm{yr}\right)$ & & & 1.5 \\
\hline Max Dry Deposition (ug/m²/yr) & & & 0.15 \\
\hline Reactive $\left(\mathrm{RGM}-\mathrm{Hg}^{+2}\right)$ & & & \\
\hline Concentration $\left(\mathrm{ug} / \mathrm{m}^{3}\right)$ & & 0.023 & \\
\hline Max Wet Deposition $\left(\mathrm{ug} / \mathrm{m}^{2} / \mathrm{yr}\right)$ & & 504 & \\
\hline Max Dry Deposition $\left(\mathrm{ug} / \mathrm{m}^{2} / \mathrm{yr}\right)$ & & 20.1 & \\
\hline Elemental $(\mathrm{Hg}(0))$ & & & \\
\hline Concentration $\left(\mathrm{ug} / \mathrm{m}^{3}\right)$ & 0.018 & & \\
\hline Max Wet Deposition $\left(\mathrm{ug} / \mathrm{m}^{2} / \mathrm{yr}\right)$ & 0.55 & & \\
\hline Max Dry Deposition (ug/m²/yr) & 0.34 & & \\
\hline
\end{tabular}

Table 3 Monticello mercury deposition summary.

\begin{tabular}{|l|c|c|c|c|}
\hline & $\mathrm{Hg}(0)$ & $\mathrm{Hg}(+2)$ & $\mathrm{Hg}(\mathrm{p})$ & Total $\mathrm{Hg}$ \\
\hline Total Mass deposited & & & & \\
\hline Wet deposition (gms) & 39 & 11681 & 39.5 & 11759 \\
\hline Dry deposition (gms) & 218 & 11378 & 2.8 & 11599 \\
\hline Total deposition (gms) & 257 & 23059 & 42.3 & 23358 \\
\hline Avg deposition rate & 0.015 & 4.7 & 0.016 & 5.0 \\
\hline $\begin{array}{l}\text { Avg Wet Deposition } \\
\left(\mathrm{ug} / \mathrm{m}^{2} / \mathrm{yr}\right)\end{array}$ & 0.1 & 4.5 & 0.001 & 4.6 \\
\hline $\begin{array}{l}\text { Avg Dry Deposition } \\
\left(\mathrm{ug} / \mathrm{m}^{2} / \mathrm{yr}\right)\end{array}$ & 0.11 & 9.2 & 0.016 & 9.3 \\
\hline Avg Total Deposition & 0.0001 & 0.021 & 0.014 & 0.013 \\
\hline Fractional Deposition & 0.0006 & 0.02 & 0.001 & 0.012 \\
\hline $\begin{array}{l}\text { Fractional Wet } \\
\text { Deposition }\end{array}$ & 0.0007 & 0.04 & 0.014 & 0.025 \\
\hline $\begin{array}{l}\text { Fractional Dry } \\
\text { Deposition }\end{array}$ & & & & \\
\hline $\begin{array}{l}\text { Fractional Total } \\
\text { Deposition }\end{array}$ & & 1 & & \\
\hline
\end{tabular}




\subsubsection{Summary of Deposition Modeling}

Major findings of the deposition modeling are:

- Wet deposition removes a large fraction of the mercury emitted during precipitation events and this deposits locally within 5 or $10 \mathrm{Km}$ of the plant.

- Only a few percent of the mercury emitted from the power plants deposits within $30 \mathrm{Km}$ of the plant.

- Reactive gaseous mercury is the primary form of mercury that is deposited.

- In the prevailing wind direction, deposition resulting from coal plant emissions can be the same order of magnitude as expected background deposition.

\section{Measuring Soil and Vegetation Concentrations of Mercury around the Monticello Coal-Fired Power Plant}

\subsection{Sampling Design}

Based on the modeled deposition analysis a soil and vegetation sampling design was selected to cover a circular region approximately $16 \mathrm{~km}$ in diameter centered around the plant. Figure 7 shows the final sampling grid which which was modified from the general layout suggested by the modeling to account for site-specific conditions (e.g., inaccessibility of sample locations). Sample locations are labeled with a letter and a number. The letter denotes the sample ring with each ring being approximately 1 mile apart. The numbering starts with the sample nearest due north labeled as 1 and proceeds clockwise around each ring. The soil samples near the lake tended to have different soil characteristics than away from the lake. They tended to be more brown or reddish in color and had higher moisture than other samples.

A total of 102 sample locations were used within $16 \mathrm{~km}$ of the Monticello plant. In addition, 5 samples locations $20-40 \mathrm{~km}$ from the site were selected for background measurements. This plant was also adjacent to a large lake and state park. At each location, three surface soil samples were collected. These samples were approximately 10 feet apart and were taken from the top $5 \mathrm{~cm}$ of soil. At the middle location a deep soil sample was taken from the $5-10 \mathrm{~cm}$ soil horizon and a vegetation sample was collected. Soil samples of approximately 100 grams weight were collected in watertight wide-mouth $250 \mathrm{~mL}$ plastic screw-top cups. Samples were collected using stainless steel trowels, which were rinsed with tap water and wiped dry between each use. Vegetation samples were collected using scissors to cut vegetation just above ground level. Blind field duplicates were collected every $10^{\text {th }}$ sample. Samples were shipped back to Brookhaven National Laboratory for analysis. Latitude and longitude for each sample location were identified using a GPS locator system with a resolution of 6 meters. 


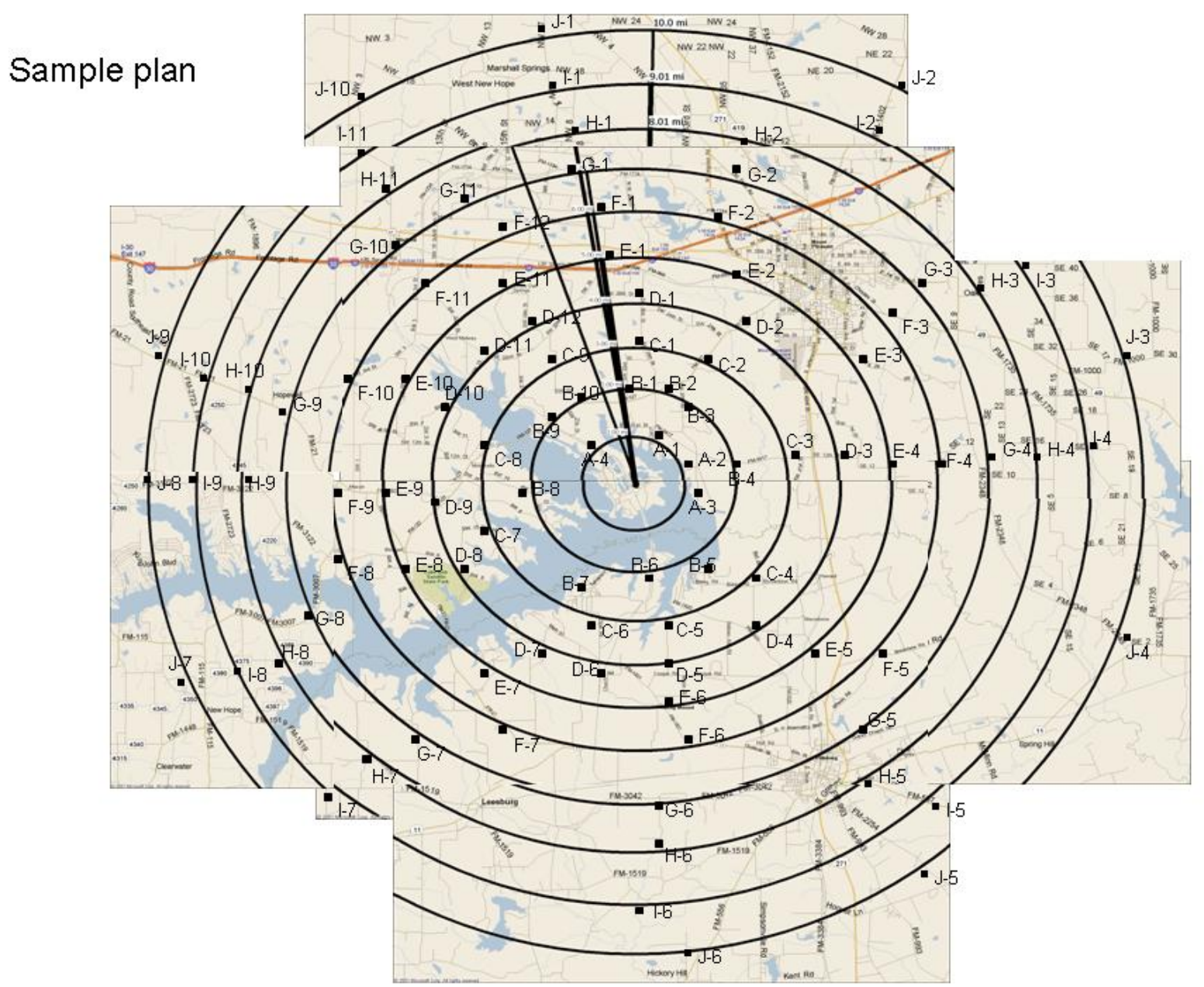

Figure 7 Sample Location Map.

\subsection{Mercury Analysis Methods and Quality Assurance}

The soil samples were analyzed using a Direct Mercury Analyzer (DMA) (DMA-80, Milestone, Inc, Monroe, CT), Figure 12. Solid samples, approximately 0.5 grams, are placed on small boats that enter the DMA. The typical working range for this method is 0.05-600 ng of mercury. Since soil samples are at most about 0.5 grams, the DMA-80 easily measures levels below $1 \mathrm{ppb}$ (ng/g). DMA-80 analyses were conducted on soil samples as received. Moisture content was determined separately for all samples, and mercury concentrations were adjusted to a dry weight basis.

Quality assurance was evaluated through taking blind duplicates of $10 \%$ of the samples, measurement of empty sample boats in the DMA-80, and use of one of two NIST mercury standards (SRM 2709 and SRM 2710) at every $10^{\text {th }}$ measurement. The NIST soil standard SRM 2709 San Joaquin soil) was used for soil measurements. It has a mercury level of $1380+/-80$ ng/g. The NIST standard SRM 2710, peach leaves, was used for vegetation samples. It has a mercury level of $31+/-7 \mathrm{ng} / \mathrm{g}$. Empty boat samples averaged $1.4 \mathrm{ng} / \mathrm{g}$ and were all less than the minimum soil sample $(10 \mathrm{ng} / \mathrm{g})$. Blind duplicates were statistically similar to the similar soil samples. Each sample was measured in triplicate to examine the homogeneity of the sample. 
The median range of the mercury levels in the three samples averaged $+/-12.5 \%$ of the average of the three samples.

\subsection{Data Analysis and Interpretation}

\subsubsection{Soil Data}

At each sample location, the three surface soil samples were averaged to give a composite. Analysis of the data shows that they are log normally distributed, as would be expected for soil samples (Tack, 2005). A total of nine values (3 locations and triplicate measures at each location) were used to estimate the average at each sample location. At the 102 locations around the plant, the average value was $33.5 \mathrm{ng} / \mathrm{g}$ (dry weight basis), with a standard deviation of 18.0. The median value was $28.5 \mathrm{ng} / \mathrm{g}$. The minimum value at any location averaged over the nine measurements was $7.6 \mathrm{ng} / \mathrm{g}$ and the maximum value was $111.4 \mathrm{ng} / \mathrm{g}$.

Figure 8a presents the measured soil concentrations and the predicted deposition contours o a base map of the Monticello area. Measured sol concentrations were grouped into 4 equal sized bins ranging from $7.6-21.7,21.7-28.4,28.4-40.4$, and $40.4-111.5 \mathrm{ng} / \mathrm{g}$. Predicted deposition contours extend over an area greater than $20 \mathrm{~km}$ from the plant at levels of 10 $\mathrm{ug} / \mathrm{m}^{2} / \mathrm{yr}$. The highest contour, $40 \mathrm{ug} / \mathrm{m}^{2} / \mathrm{yr}$, lies along the north-south axis for approximately 10 $\mathrm{km}$ centered on the plant. Again, the predicted deposition pattern does not match the measured soil $\mathrm{Hg}$ pattern well. Values in the upper $25 \%$ of the soil $\mathrm{Hg}$ distribution $(\mathrm{Hg}>40.4 \mathrm{ng} / \mathrm{g}$ ) tended to be close to the lake. In reviewing the soil characteristics, soils with high levels of mercury tended to be brown or dark brown in color while those with low mercury levels were gray or light brown and sandy. The dark brown color suggests a higher organic content in these soils and mercury is known to preferentially accumulate in organic matter. However, the organic content has not been determined. There was a strong correlation between surface and deep samples, further supporting the importance of soil characteristics as controlling mercury levels. At Monticello, the deep samples averaged slightly greater mercury levels than the surface samples, but the difference was not statistically significant. 

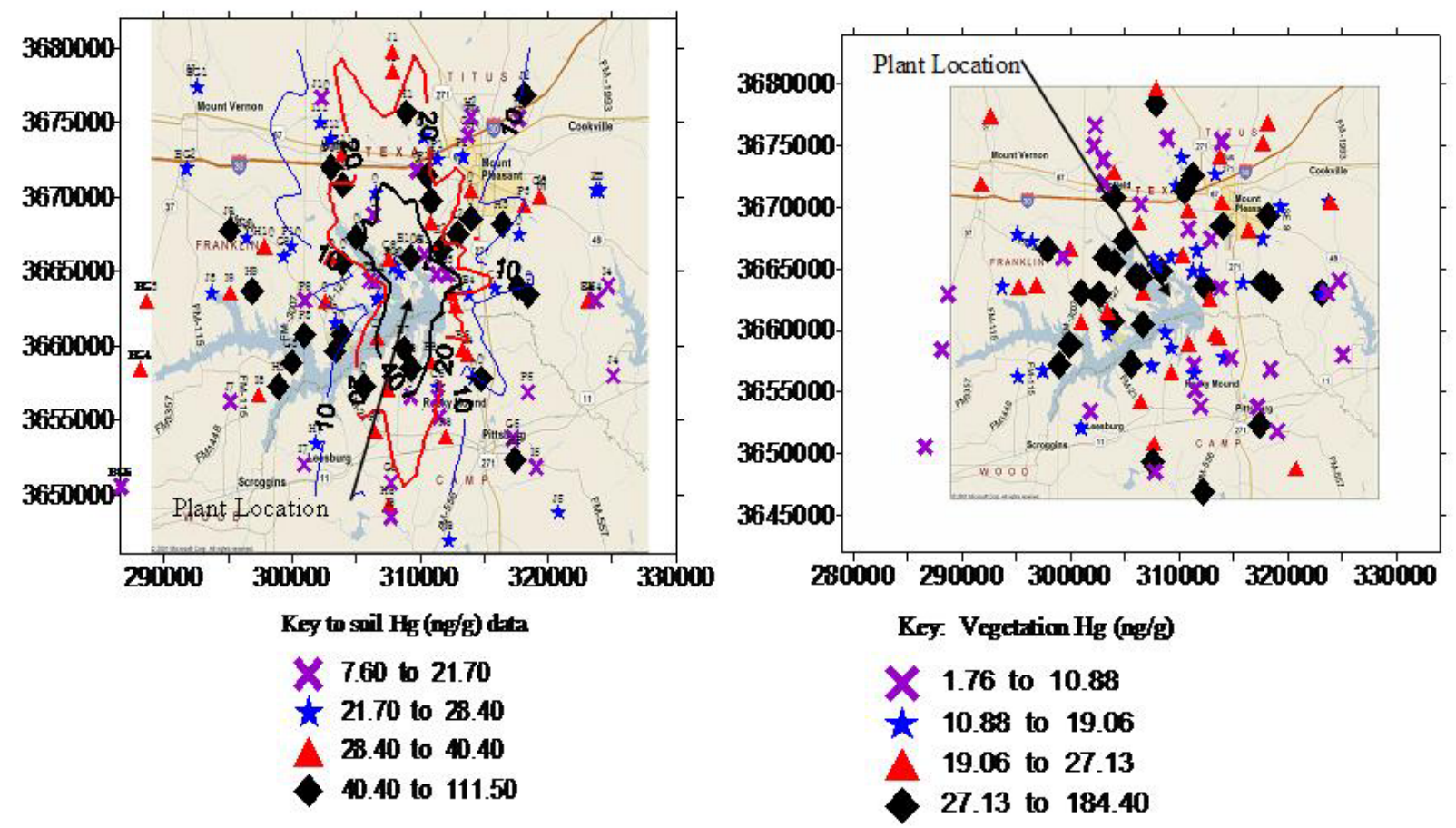

Figure 8 a) Measured soil $\mathrm{Hg}$ (ng/g) concentrations with predicted deposition contours, and b) Measured vegetation $\mathrm{Hg}$ (ng/g) concentrations near the Monticello Plant.

Figure $8 \mathrm{~b}$ shows the vegetation $\mathrm{Hg}$ concentrations around the Monticello site. There was a good correlation between high mercury in the soil and vegetation. The spread in the data for vegetation was larger than for soil, perhaps reflecting a wider range of vegetation types. At this site, vegetation ranged from grass covered soils to nearly bare soils with a few weeds. It was not possible to collect grass samples from all sites.

\section{Conclusions}

A thorough quantitative understanding of the processes of mercury emissions, deposition, and translocation through the food chain is currently not available. Complex atmospheric chemistry and dispersion models are required to predict concentration and deposition contributions, and aquatic process models are required to predict effects on fish. There are uncertainties in all of these predictions. Therefore, the most reliable method of understanding impacts of coal-fired power plants on $\mathrm{Hg}$ deposition is from empirical data.

A review of the literature on mercury deposition around sources including coal-fired power plants found studies covering local mercury concentrations in soil, vegetation, and animals (fish and cows (Lopez et al. 2003). There is strong evidence of enhanced local deposition within $3 \mathrm{~km}$ of the chlor-alkali plants, with elevated soil concentrations and estimated deposition rates of 10 times background. For coal-fired power plants, the data show that atmospheric deposition of $\mathrm{Hg}$ may be slightly enhanced. On the scale of a few $\mathrm{km}$, modeling suggests that wet deposition may be increased by a factor of two or three over background. The measured data suggest lower increases of $15 \%$ or less. The effects of coal-fired plants seem to be less than $10 \%$ of total deposition on a national scale, based on emissions and global modeling. 
The following summarizes our findings from published reports on the impacts of local deposition. In terms of excesses over background the following increments have been observed within a few km of the plant:

- local soil concentration $\mathrm{Hg}$ increments of 30\%-60\%,

- sediment increments of 18-30\%, and

- wet deposition increments of $11-12 \%$.

- fish $\mathrm{Hg}$ increments of about 5-6\%, based on an empirical finding that fish concentrations are proportional to the square root of deposition.

Important uncertainties include possible reductions of $\mathrm{RGM}$ to $\mathrm{Hg}(0)$ in power plant plumes and the role of water chemistry in the relationship between $\mathrm{Hg}$ deposition and fish content.

Soil and vegetation sampling programs were performed around the Monticello coal fired power plant. The objectives were to determine if local mercury hot spots exist, to determine if they could be attributed to deposition of coal-fired power plant emissions, and to determine if they correlated with model predictions. The study found the following:

- There was no correlation between modeled mercury deposition and either soil concentrations or vegetation concentrations. At the Monticello plant, excess soil $\mathrm{Hg}$ was associated with soil characteristics with higher values near the lake. Vegetation concentration showed some correlation with soil concentrations having higher mercury in vegetation when the soil mercury

- The subsurface $(5-10 \mathrm{~cm})$ samples the $\mathrm{Hg}$ concentration correlated strongly with the surface samples $(0-5 \mathrm{~cm})$. Average subsurface sample concentrations were slightly larger than the surface samples, however, the difference was not statistically significant.

- An unequivocal definition of background $\mathrm{Hg}$ was not possible. Soil characteristics had better correlation with mercury content than distance from the plant.

- Based on computer modeling, Hg deposition was primarily RGM with much lower deposition from elemental mercury. The total deposition within $50 \mathrm{Km}$ of the plant was predicted to be $4.2 \%$ of the total emitted. In the deposition, RGM is responsible for $98.7 \%$ of the total deposition, elemental mercury accounts for $1.1 \%$ and particulate mercury accounts for $0.2 \%$. Less than $1 \%$ of the elemental mercury emitted was predicted to deposit within $50 \mathrm{~km}$.

- Predicted deposition could be more than 3 times the estimated background for a $10 \mathrm{~km}$ region centered around the plant in the direction of the prevailing winds. However, soil and vegetation samples did not match the predicted increase in deposition.

The major objective of this study was to determine if there was evidence for "hot spots" of mercury deposition around coal-fired power plants. Although the term has been used extensively, it has never been adequately defined. From a public health perspective, such a "hot spot" must be large enough to insure that it did not occur by chance, and it must affect water bodies large enough to support a population of subsistence fishers. The results of this study support the hypothesis that large areas of elevated mercury concentrations do not exist around the Monticello power plant. This does not mean that there is no effect, but rather that the effects are small 


\section{References}

Abbott ML, Susong DD, Olson M, Krabbenhoft DP. Mercury in soil near a long-term air emission source in southeastern Idaho, Environmental Geology (2003) 43:352-356.

Anderson WL, Smith KE. Dynamics of Mercury at a Coal-Fired Power Plant and Adjacent Cooling Lake, Environ Sci Tech,(1977),11:75-80.

Biester H, Muller G, Scholer HF. Estimating distribution and retention of mercury in three different soils contaminated by emissions from chlor-alkali plants, Science of Tot Env (2002),284:177-189.

Biester H, Muller G, Scholer HF. Binding and mobility of mercury in soils contaminated by emissions from chlor-alkali plants, Science of Tot Env(2002a) 284: 191-203.

Cox WM., Rorex HW, Moss GK. Evaluation of Rural Air Quality Simulation models, Addendum C: Kincaid $\mathrm{SO}_{2}$ Data Base, EPA-450/83-003c, U.S. Environmental Protection Agency, Research Triangle Park, NC, March 1986.

Crockett A., Kinnison RH. Mercury Residues in Soil around a Large Coal-Fired Power Plant, Environ Sci Tech (1979) 13:712-5.

Edgerton E, Hartsell B, Jansen J. "Hg Speciation in Coal-Fired Power Plant Plumes: Evidence for Reduction of RGM to $\mathrm{HG}(0), " 7^{\text {th }}$ Annual Conference on Mercury as a Global Pollutant, Ljubljana, Slovenia, July 2, 2004.

U.S. Environmental Protection Agency, User's Guide for the Industrial Source Complex (ISC3) Dispersion Models, Volume I - User Instructions, EPA-454/B-95-003A, Office of Air Quality Planning and Standards Emissions, Monitoring, and Analysis Division, Research Triangle Park, NC. 1995

U.S. Environmental Protection Agency, Fate and Transport of Mercury in the Environment, Mercury Study Report to Congress, vol. III, EPA-452/R-970995, 1997.

U.S. Environmental Protection Agency, State Mercury Emissions Estimates from Power plants, June 2001, http://www.epa.gov/ttn/atw/combust/utiltox/utoxpg.html\#DA1.

Environmental Science and Technology Science Page, "Controversial Results Downplay Power Plant Mercury Emissions,” Nov. 3, 2004. http://pubs.acs.org/subscribe/journals/esthagw/2004/nov/science/rr_mercury.html

Klein DH, Russell P. Heavy Metals: Fallout around a Power Plant, Environ Sci Tech (1973) 7:357-8. 
Kotnik J, Horvat M., Mandic V, Logar M. Influence of the Sostanj coal-fired thermal power plant on mercury and methyl mercury concentrations in Lake Velenje, Slovenia, Science Total Environ (2000), 259:85-95.

Laudal D, Dunham G, Levin L. Mercury Control Technology R\&D Review, Pittsburgh, PA, July $14-15,2004$.

http://www.netl.doe.gov/publications/proceedings/04/HgReview/Laudal2.Presentation\%20for\%2 0Project\%20Review\%20Meeting\%20Plume\%20Study\%20-\%20Pittsburgh\%20July\%2014-

15\%202004\%20-\%202.pdf

Lodenius M. Dry and wet deposition of mercury near a chlor-alkali plant, Science Tot Environ (1998), 213: 53-56.

Lopez Alonzo M., Benedito JL, Miranda M, Fernandez JL, Castillo C, Hernandez J. Shore, R.F., Environ Pollut (2003), 125:173-81.

Mercury Deposition Network, http://nadp.sws.uiuc.edu/mdn.

Menounou N, Presley BJ. Mercury and other trace elements in sediment cores from central Texas lakes, Arch Environ Contam Toxicol (2003), 45:11-29.

Sensen M, Richardson DHS. Mercury levels in lichens from different host trees around a chloralkali plant in New Brunswick, Canada., Science Tot Environ (2002),293:31-45.

Southworth GR, Lindberg SE, Zhang H. Anscombe, F.R., Fugitive mercury emissions from a chlor-alkali factory; sources and fluxes to the atmosphere, Atmospheric Environment (2004) 38:597-611.

Sullivan TM, Lipfert FD, Morris SC, Moskowitz PD. Potential Health Risk Reduction Arising From Reduced Mercury Emissions from Coal-Fired Power Plants, FY 2001 Report, September, 2001, BNL-71538-2003.

Sullivan TM, Lipfert FD, Morris SM. The Local Impacts of Mercury Emissions from Coal Fired Power Plants on Human Health Risk, Progress Report for the Period of March 2002 - March 2003, BNL-71554-2003, May 2003.

Sullivan TM, Bowerman B, Adams J, Lipfert FD, Morris SM, Bando A, Pena R, Blake R. Mercury Emissions from Coal Fired Power Plants: Local Impacts on Human Health Risk, BNL topical report in press (2005).

Susong DD, Abbott ML, Krabbenhoft DP. "Mercury accumulation in snow on the Idaho National Engineering and Environmental Laboratory and surrounding region, southeast Idaho, USA, Environmental Geology (2003), 43:357-363.

Tack FMG, Vanhaesebroeck T, Verloo MG, Van Rompaey K, Van Ranst E. Mercury baseline levels in Flemish soils (Belgium), “ Environmental Pollution (2005),134:173-179. 
Tobias FJ, Bech J, Sanchez Algarra P. Statistical Approach to Discriminate Background and Anthropogenic Input of Trace Elements in Soils of Catalonia, Spain, Water Air and Soil Pollution (1997), 100:63-78.

Wang D, Shi X., Wei S. Accumulation and transformation of atmospheric mercury in soil, Science Tot Environ (2003), 300:209-214.

Xiao Z, Smar J, Lindqvist O, Giouleka E. Atmospheric mercury deposition to grass in southern Sweden, Science Tot Environ (1998),213: 85-94. 